\title{
A Política na Alcova: Ecos Espinosanos em Sade ${ }^{1}$
}

\author{
Mario Videira ${ }^{2}$
}

\begin{abstract}
RESUMO: O presente artigo tem por objetivo investigar a recepção do Tratado Teológico-Político de Espinosa, bem como sua crítica da religião pelo Marquês de Sade, numa obra bastante peculiar e que desafia todas as tentativas de classificação: La Philosophie dans le Boudoir. Em seu "Quinto Diálogo", Sade insere um texto intitulado "Franceses, mais um esforço se quereis ser Republicanos". Através do emprego desse artifício metalinguístico - um livro dentro de um livro - a política é agora introduzida na alcova e o leitor se dá conta de que a instrução de Eugénie não é meramente sexual, mas também uma educação filosófica e política. Por meio de sua crítica ao Cristianismo, na primeira seção do texto, Sade argumenta que a tirania e a superstiçẫo religiosa são âmbitos intimamente relacionados, e a teologia é um dos principais alicerces do poder político.
\end{abstract}

PALAVRAS-CHAVE: Sade (1740-1814). Espinosa (1632-1677). Tirania e superstição religiosa. A filosofia na alcova. Tratado teológico-político.

\section{INTRODUÇáo}

Desde a Antiguidade, Filosofia e Literatura sempre se relacionaram de maneira bastante íntima: diálogos, cartas, discursos, confissóes e aforismos são algumas das formas usadas por filósofos para a escrita de seus textos. Sobretudo durante o Iluminismo francês, Filosofia e Literatura fundiram-se de uma maneira especialmente fértil: Voltaire, Rousseau, Diderot e Sade são apenas alguns exemplos dessa união.

Neste artigo, pretendo investigar aspectos da recepção do Tratado Teológico-Político de Espinosa pelo Marquês de Sade, por meio de sua crítica à religião, em uma obra bastante peculiar e que desafia quaisquer tentativas rígidas de classificação: A Filosofia na Alcova. Esse livro é, talvez, a mais célebre obra escrita pelo Marquês de Sade (1740-1814). Publicado anonimamente

\footnotetext{
${ }^{1}$ http://dx.doi.org/10.1590/S0101-31732016000500002

${ }^{2}$ Doutor em Filosofia pela Universidade de São Paulo e Mestre em Musicologia pela Universidade Estadual Paulista. Desde 2010, atua como professor e pesquisador do Departamento de Música da Escola de Comunicações e Artes da USP. É autor de O Romantismo e o Belo Musical (Ed. Unesp, 2006) e tradutor de Berg: o mestre da transição mínima, de T. W. Adorno (Ed. Unesp, 2010). Além disso, publicou diversos artigos sobre Estética e Filosofia da Música em revistas especializadas, tanto no Brasil como no exterior. mario.videira@usp.br
} 
em $1795^{3}$, ele está dividido em sete "Diálogos”, escritos de maneira similar a uma peça teatral. ${ }^{4}$ A ação se passa na residência de Madame de Saint-Ange, uma charmosa libertina de vinte e seis anos, que toma para si a tarefa de educar a bela e jovem Eugénie. ${ }^{5}$ Tal tarefa é levada a cabo com o auxílio de seu irmão, o Chevalier de Mirvel, e por Dolmancé, um sodomita de trinta e seis anos, extremamente inteligente e bem-apessoado, dotado de uma extraordinária mente filosófica, e também “[...] o mais célebre ateu, o mais imoral dos homens [...] e da mais extrema e completa corrupção, o indivíduo mais celerado e cruel que possa haver no mundo"(SADE, 1999, p.16): ele possui "[...] precisamente o grau de filosofia necessária" (SADE, 1999, p. 25) para a educação de Eugénie. Sem sombra de dúvidas, Dolmancé é o melhor preceptor para formar e conduzir Eugénie "[...] na carreira da felicidade e dos prazeres.” (SADE, 1999, p. 26) E como eles planejam essa educação? SaintAnge explica: "Dolmancé e eu incutiremos em sua linda cabecinha todos os princípios da libertinagem mais desenfreada [...]; nossa filosofia lhe servirá de alimento e nossos desejos de inspiração." (SADE, 1999, p.19) Unindo conhecimento teórico e lições práticas, o principal objetivo pedagógico será o de corromper a inocente Eugénie, abafando em seu jovem coração "[...] as sementes de virtude e de religião que suas preceptoras lhe incutiram"(SADE, 1999, p. 20), pervertendo e demolindo "[...] todos os falsos princípios morais com que já a atordoaram.” (SADE, 1999, p. 20). Como ficará claro ao longo do livro, Eugénie é uma aluna extremamente dócil e diligente. Logo no início de seu diálogo com Saint-Ange, ela declara: "Vim aqui para me instruir e só irei embora quando for sábia.”(SADE, 1999, p. 23). De braços dados com Madame de Saint-Ange, elas entram no boudoir. A educação de Eugénie está por começar.

\footnotetext{
3 “Embora anônimo, ele foi publicado como uma 'obra póstuma do autor de Justine', um subterfúgio que Sade iria utilizar dois anos mais tarde para a publicação de La Nouvelle Justine. O local de publicação da edição original foi indicado como sendo Londres, aux dépens de la Compagnie, e além de um frontispício alegórico, continha quatro gravuras eróticas. A epígrafe da edição original é a seguinte: 'A mãe prescreverá sua leitura à filha.' Uma segunda edição, em dois volumes in-octavo de 203 e 191 páginas, respectivamente, apareceu dez anos mais tarde, em 1805, com a adição de um subtítulo - pelo qual Sade, que se encontrava no asilo de Charenton, dificilmente poderia ter sido responsável - ou les instituteurs immoraux (ou os preceptores imorais)". (SADE, 1990, p. 179).

4 "Uma espécie de romance, na forma de diálogo, apresentado como um espetáculo; uma composição dramática cujo teor é sublinhado pelas indicaçôes do movimento dos atores e de seus apartes, que vêm postos entre parênteses.” (LEFORT, 1999, p. 95).

${ }^{5}$ Numa de suas falas, Saint-Ange afirma: "Trata-se de uma educação; é uma garota que conheci no convento o outono passado [...]. Pretendo a maior parte do tempo cuidar da educaçáo da moça." (SADE, 1999, p. 19).
} 


\section{2 “UM POUCO DE TEORIA É SEMPRE BOM DEPOIS DA PRÁTICA" OU: “Franceses, MAIS UM ESFORÇO SE QUEREIS SER REPUBLICANOS”}

No "Quinto Diálogo", depois das exaustivas liçóes práticas ministradas à dócil e receptiva aluna, Eugénie sugere que se faça uma pequena pausa: "Sentemo-nos e conversemos um pouco; não aguento mais. Continuai minha instruçáo, Dolmancé, mas dizei algo que me console dos excessos a que me entreguei; apaziguai meus remorsos, dai-me coragem." (SADE, 1999, p. 123). Saint-Ange concorda com ela: "Isso é justo; um pouco de teoria é sempre bom depois da prática; é o meio para se tornar uma aluna perfeita." Após ser questionada por Dolmancé acerca de qual tema ela gostaria de conversar, ela responde: "Gostaria de saber se os costumes são verdadeiramente necessários num governo, se sua influência tem algum peso sobre o gênio de uma nação."(SADE, 1999, p. 123). Esta é a deixa para o início da discussão política na esfera privada da alcova. Dolmancé relata ter comprado, naquela mesma manhá, no Palácio da Igualdade, uma pequena brochura que certamente deverá responder à questão de Eugénie. Seu título: Franceses, mais um esforço se quereis ser Republicanos. Por meio do uso desse artificio metalinguístico um livro no interior do livro - a política entra na discussão. Nesse momento, o leitor se dá conta de que a instrução de Eugénie não é apenas sexual: tratase, sobretudo, de uma educação filosófica e política. Na primeira seção ${ }^{6}$ desse texto, Sade faz uma crítica feroz do Cristianismo, mostrando que a tirania e a superstição religiosa são os dois lados de uma mesma moeda, já que a teologia é um dos principais alicerces do poder político.

O autor da brochura é um Republicano convicto e admirador da Revolução Francesa. No entanto, a seu ver, a Revolução ainda não está concluída: é com pesar que ele vê a lentidão com que se tenta atingir a meta da implantação da República e o inquieta o sentimento de que os franceses se encontram às vésperas de fracassar novamente. Para que se atinja a meta republicana, não bastam as leis: "Que faríamos das leis sem a religiáo? Precisamos de um culto, e um culto feito para o caráter de um republicano”. (SADE, 1999, p. 125, grifo nosso). ${ }^{7}$ A todo momento, ele reconhece que a

\footnotetext{
${ }^{6} \mathrm{O}$ texto está dividido em duas seçôes, intituladas, respectivamente: "A Religiāo" e "Os Costumes".

${ }^{7}$ Mais adiante, o autor esclarece quais seriam as características desse culto republicano: "Já que acreditamos ser um culto necessário, imitemos o dos romanos: açôes, paixôes, heróis, eis seus respeitáveis objetos. [...] $\mathrm{O}$ adorador de Minerva queria ser prudente. A coragem estava no coraçáo daquele que se via aos pés de Marte. [...] O que vemos, ao contrário, nos deuses vấos do cristianismo? O que vos oferece essa religiáo imbecil? [...] Encontrais entre os santos que guarnecem seu Eliseu algum modelo de grandeza, de heroísmo ou de virtude? [...] Este deus quimérico, prudentemente inventado pelos
} 
religião cristã era uma das melhores armas nas mãos dos tiranos. Sua principal crítica é contra a superstição religiosa:

Em menos de dez anos, mediante a religião cristấ, sua superstição, seus preconceitos, vossos padres $[\ldots]$ retomariam sobre as almas o império que haviam invadido; eles vos acorrentariam novamente aos reis, pois o poder destes sempre apoiou o outro, e vosso edifício republicano se desmoronaria por falta de bases. (SADE, 1999, p. 126, grifo nosso).

É preciso, portanto, desferir o derradeiro golpe na árvore da superstição: "[...] náo vos contenteis com podar os ramos. Desenraizai de uma vez uma planta cujos efeitos são tão contagiosos."(SADE, 1999, p. 126). É somente através do aniquilamento dessa árvore da superstição que poderá surgir a árvore da liberdade. É somente por meio do combate aos preconceitos religiosos, aos "[...] dogmas absurdos, a moral impossível dessa religião repelente"(SADE, 1999, p. 127) que a República poderá ser erigida. Como se vê, o autor do texto defende a ideia de que a religiáo e a tirania estáo sempre intimamente relacionadas e que, portanto, é preciso combater ambas: "Eu vos repito, franceses: a Europa espera que vós a liberteis de uma vez do cetro e do incensório." (SADE, 1999, p.127). É impossível livrar as pessoas da tirania monárquica sem, ao mesmo tempo, romper as amarras da superstiçáa religiosa: "[...] os laços que unem ambas estão por demais unidos [...] para que, deixando uma delas subsistir, não tombeis de novo sob o império daquela que tiverdes negligenciado em dissolver." (SADE, 1999, p.127). Como os reis sempre apoiaram a religiáo e esta, por sua vez, sempre consagrou os reis, fica claro que toda religião deve ser destruída, se quisermos construir e consolidar um regime republicano: "[...] não nos contentemos em quebrar os cetros; pulverizemos para sempre os ídolos.”(SADE, 1999, p.130) O autor defende ainda que a superstição sempre esteve a apenas um passo do realismo e que os reis sempre se preocuparam em manter a religião dominante como "[...] uma das melhores bases políticas de sustentação do trono." (SADE, 1999, p.130). No entanto, já que o trono foi derrubado, é preciso extirpar também aquilo que lhe servia de apoio, a saber, a religião:

[...] jamais seus dogmas, seus ritos, seus mistérios ou sua moral convirão a um republicano. Mais um esforço! Já que trabalhais para destruir todos os preconceitos, não deixais subsistir nenhum, se apenas um basta para trazer

primeiros legisladores, não passava em suas mãos de um meio a mais para nos acorrentar, e que, reservando-se o direito de só fazer falar este fantasma, saberiam fazê-lo dizer apenas o que serviria de apoio às leis ridículas por meio das quais pretendiam nos escravizar."(SADE, 1999, (p. 128-129). 
todos de volta. [...] Deixemos de acreditar que a religião possa ser útil ao homem. Tenhamos boas leis, e passaremos bem sem a religião. (SADE, 1999, p.130).

Alguns dos argumentos usados pelo autor desse texto, com o intuito de alertar acerca dos perigos decorrentes da aliança entre despotismo e religiáo, são bastante similares àqueles utilizados no Tratado Teológico-Político de Espinosa. ${ }^{8}$ Com efeito, no tratado de Espinosa, medo e esperança são os afetos que desempenham o papel principal na manutenção da superstição religiosa. Da mesma forma, para o autor de Franceses, mais um esforço se quereis ser Republicanos, as religiōes são o berço do despotismo e, por sua vez, as bases sobre as quais todas as religiôes estão fundadas são: ignorância e medo (SADE, p. 134). Uma vez que a religião fornece as bases sobre as quais se alicerça o despotismo, ele pergunta:

Se se deixarem subsistir as bases do edifício que se acreditava destruído, o que acontecerá? Reconstruir-se-á sobre estas bases, e sobre elas serão erigidos os mesmos colossos [...]. Que jamais se duvide que as religióes sejam o berço do despotismo. [...] em todos os tempos, em todos os séculos, houve entre o despotismo e a religiáo uma tal conexão, que está mais do que demonstrado que destruindo um se derrubará o outro. (SADE, 1999, p. 135).

No final dessa primeira parte do texto de Sade também encontramos ecos de argumentos espinosanos:

[...] o verdadeiro amigo da pátria não deve, como o escravo dos reis, ser ameaçado por quimeras; que não é, afinal, nem a esperança frívola de um mundo melhor, nem o medo de males maiores do que aqueles que a natureza nos envia que devem conduzir um republicano, cujo único guia é a virtude e o único freio, o remorso. (SADE, 1999, p.136, grifo nosso).

Para que possamos compreender melhor tais referências ao medo e à esperança, bem como suas conexốes com uma possível recepção do pensamento espinosano, na escrita desse texto, convém voltarmos um pouco nossa atenção

\footnotetext{
${ }^{8}$ Deve-se notar que, dentre os livros da biblioteca de Sade, encontram-se: o Tractatus, de Espinosa (traduzido por Saint-Glam), Élements philosophiques, de Hobbes, Analyse de la religion chrétienne, de Voltaire, o Traité des trois imposteurs (de autor anônimo), a Histoire de la superstition, de D'Holbach, dentre outros. A esse respeito, ver: Mothu ([20--?]) Les lectures “nécessaires” du Marquis de Sade.
} 
a alguns aspectos da crítica da superstição religiosa feita por Baruch de Espinosa, em seu Tratado Teológico-Político.

\section{Medo e Esperança: as raízes da superstição no Tratado Teológico- Político de EsPinosa}

Logo na abertura do "Prefácio" ao Tratado Teológico-Politico, Espinosa expôe a hipótese sob a qual os homens jamais seriam vítimas da superstição: se pudessem, em todas as circunstâncias, decidir pelo seguro ou se a fortuna ${ }^{9}$ se lhes mostrasse sempre favorável (ESPINOSA, 2003, p. 5).${ }^{10}$ Porém, o filósofo nega tal hipótese, logo em seguida:

Mas, como se encontram frequentemente perante tais dificuldades que não sabem que decisão hão de tomar, e como os incertos benefícios da fortuna que desenfreadamente cobiçam os fazem oscilar, a maioria das vezes, entre a esperança e o medo, estão sempre prontos a acreditar seja no que for. (TTP, 2003, p. 5).

Diante da impossibilidade de deliberação segura e do desejo desenfreado de bens incertos da fortuna, ou seja, em face da experiência da contingência das coisas, os homens oscilam incessantemente entre a esperança e o medo.

Na Parte III da Ética, Espinosa apresenta as definiçóes dessas duas paixóes. Assim, a esperança é definida como "[...] uma alegria ${ }^{11}$ instável nascida da ideia de uma coisa futura ou passada, do resultado da qual duvidamos numa certa medida."(ESPINOSA, 1983) Por sua vez, Espinosa define o medo como "[...] uma tristeza instável nascida da ideia de uma coisa futura ou passada, do resultado da qual duvidamos numa certa medida," A partir dessas definiçóes, Espinosa conclui que não há esperança sem medo, nem medo sem esperança.

\footnotetext{
${ }^{9}$ Entende-se aqui por Fortuna a contingência absoluta, aquilo sobre o qual não temos controle. $\mathrm{Na}$ mitologia, a Fortuna era uma deusa importantíssima, no panteão romano. Uma das mais célebres representaçōes da Fortuna pode ser encontrada na História de Heródoto, na qual podemos ler que "[...] a Fortuna jamais cessa de girar sua roda, rebaixando os que foram por ela elevados e elevando os que foram por ela rebaixados" (apud CHAUÍ, 2002, p. 163).

10 Espinosa (2003)Tratado Teológico-Político (doravante, TTP), p. 5.

${ }^{11}$ Espinosa. Ética (Parte III), 1983 (doravante EIII). Espinosa considera que os homens possuem três afetos originários, a saber: 1) alegria, ou seja, a passagem do homem de uma perfeição menor para uma maior; 2) tristeza, ou seja, a passagem do homem de uma perfeiçáo maior para uma menor; 3) desejo, "[...] a própria essência do homem, enquanto esta é determinada a fazer algo por uma afecção nela verificada.” (EIII Def 1-3).
} 
Com efeito, "[...] aquele que está em suspenso pela esperança [...] enquanto está em suspenso pela esperança, tem medo de que a coisa náo aconteça. Aquele que, ao contrário, é vítima do medo [...] tem esperança de que essa coisa não aconteça."(EIII Def 12-13 e explicação). O medo e a esperança são, portanto, afetos simultâneos e instáveis, decorrentes da representação do futuro como algo contingente.

Um pouco mais adiante, Espinosa definirá a segurança como “[...] a alegria nascida de uma coisa futura ou passada, acerca da qual já não há causa de dúvida"; e o desespero como "[...] uma tristeza nascida de uma coisa futura ou passada, acerca da qual já não há mais causa da dúvida.” A partir disso, ele afirma que a segurança, portanto, nasce da esperança, e o desespero [nasce] do medo, "[...] quando já não há causa de dúvida acerca do resultado de uma coisa."(EIII Def 14-15 e explicação). Assim, podemos sustentar que a segurança e o desespero são os afetos que nós temos quando não possuímos mais dúvida ${ }^{12}$ sobre o futuro (ou sobre o passado), ou seja, quando nós temos uma imagem tal da coisa futura (ou da coisa passada) que não podemos duvidar. A peculiaridade da segurança e do desespero é que eles são uma alegria ou uma tristeza estáveis. E o que permite o surgimento da segurança e afastamento do desespero é uma relação com o tempo em que não cabe mais a dúvida. ${ }^{13} \mathrm{Na}$ medida em que os homens cobiçam bens incertos da fortuna, sobre os quais não podem ter nenhuma certeza, eles oscilam sem cessar entre o medo e a esperança.

Em seguida, Espinosa descreve o efeito do desejo imoderado dos bens contingentes e os efeitos do medo e da esperança. Levados pelas paixóes e pelo desejo daquilo que não está no poder dos homens (porquanto o que desejam é contingente), eles oscilam entre várias atitudes possíveis: a credulidade, a hesitação e o orgulho. Ninguém ignora quais são os efeitos do medo e da esperança, quando o que os determina é o desejo desenfreado de bens contingentes. Entretanto,

\footnotetext{
${ }^{12}$ Ainda na Explicação das Definiçôes 13 e 14 da Ética (Parte III), Espinosa escreve: "Na verdade, embora jamais possamos estar certos do resultado das coisas singulares, pode, todavia, acontecer que não duvidemos dele. Demonstramos, com efeito, que uma coisa é não duvidar de uma coisa e outra coisa é ter a certeza a respeito dela; e, por conseguinte, pode acontecer que sejamos afetados pela imagem de uma coisa passada ou futura, da mesma afecçáo de alegria ou de tristeza que pela imagem de uma coisa presente."

${ }^{13}$ Com efeito, Espinosa escreve: "[...] a esperança não é senão uma alegria instável, nascida da imagem de uma coisa futura ou passada, de cujo resultado duvidamos; o medo, ao contrário, é uma tristeza instável, nascida também da imagem de uma coisa duvidosa. Se se retira a dúvida dessas afecçóes, a esperança transforma-se em segurança e o medo em desespero, a saber, a alegria ou tristeza nascida da imagem de uma coisa que tememos ou esperamos." (EIII P18 S2).
} 
todos ignoram por que isso acontece. Porque os homens se ignoram a si mesmos é que eles desejam imoderadamente esses bens que são contingentes. Assim, a impossibilidade de deliberar com certeza e a ignorância acerca de si mesmos é que deixa os homens à mercê da fortuna, e essa instabilidade é experimentada sob a forma do medo e da esperança simultâneas. ${ }^{14}$

Nessa relação com um tempo fragmentado, nessa incerteza perante a experiência do contingente, a imaginação tenta conectar os instantes dispersos da experiência temporal, por meio da crença em presságios e milagres, como resultados de uma ação divina inexplicável. Os homens que estáo submersos na superstição interpretam a natureza da maneira mais extravagante, como se toda ela delirasse ao mesmo tempo que eles. Isso os leva a considerar a razão como cega (“[...] porque não pode indicar-lhe um caminho seguro em direção às coisas vấs que eles desejam”), ou a considerar inútil a sabedoria humana. Em contrapartida, "[...] os devaneios da imaginação, os sonhos e as extravagâncias infantis, parecem-lhes respostas divinas." Espinosa conclui que o medo "[...] é a causa que origina, conserva e alimenta a superstiçáo." (TTP, 2003, p. 3). Daí ele conclui: 1) que todos os homens lhe estão naturalmente sujeitos (pois ela provém de uma paixáo); 2) que ela deve ser extremamente variável e inconstante (pois, dependendo da circunstância, mudam nossos medos e nossa esperança); 3) “[...] que só a esperança, o ódio, a cólera e a fraude podem fazer com que subsista, pois não provêm da razão, mas unicamente da paixão, e da paixão mais eficiente."(TTP, 2003, p. 7).

\section{Como bem observa Marilena Chauí (1995, p. 35):}

Eis por que a casta religiosa, visando manter o domínio sobre a alma supersticiosa, precisa estabilizar nossos medos e esperanças e impedir que mudem ou flutuem. Ela o faz codificando as revelaçóes divinas, estabelecendo leis, regras e mandamentos fixos que teriam sido ordenados eternamente por Deus, punindo com a morte e a tortura os transgressores e estabelecendo, para a sustentaçáo de seu poderio, um aparato militar e

\footnotetext{
${ }^{14}$ No ensaio "O retorno do teológico-político", Marilena Chauí descreve da seguinte forma a situação desses homens: "Têm medo que males lhes aconteçam e bens não lhes aconteçam, assim como têm esperança de que bens lhes advenham e males não lhes caiam sobre as cabeças. Visto que bens e males, não parecendo depender deles próprios, lhes parecem depender inteiramente da fortuna ou do acaso, e como reconhecem que as coisas que assim lhes acontecem são efêmeras, seu medo e sua esperança jamais cessam, pois, da mesma maneira que coisas boas ou más lhes vieram sem que soubessem como nem porquê, também podem desaparecer sem que saibam as razóes desse desaparecimento. A gênese da superstiçăo encontra-se, portanto, na experiência da contingência. A relação imponderável com um tempo cujo curso é ignorado [...] gera simultaneamente a percepção do efêmero e do tempo descontínuo, o sentimento da incerteza e da imprevisibilidade de todas as coisas". (CHAUÍ, 2004, p. 115-116).
} 
político que opera por meio do terror, amedrontando os transgressores com ameaças de castigos e adulando o servilismo dos obedientes com promessas de recompensas. Assim, a tirania religiosa e a política fundam-se no medo e na esperança irracionais, alimentando-os com nossa ignorância sobre a verdade de Deus, da natureza e de nós mesmos.

Ora, uma vez que os regimes políticos violentos "[...] são conservados por meio da superstição, do medo de castigos, da esperança de benefícios, da censura do pensamento e da palavra, da submissão aos poderes religiosos"(CHAUI, 1995, p. 78), e porque o texto sagrado é "torturado" pelos teólogos, a fim de manipulá-lo politicamente (eles se baseiam nas Sagradas Escrituras para justificar o poder que exercem), é que Espinosa irá propor um novo método interpretativo, o qual se afasta tanto da tradição interpretativa alegórica quanto daquela que separa o espírito e a letra. $\mathrm{O}$ método interpretativo espinosano será histórico, crítico e filológico (CHAUI, 2003 , p. 17), e a principal consequência da exegese bíblica será a separação entre fé e razão, entre teologia e filosofia (CHAUI, 2003, p. 32). Na Carta XXX (a Oldenburg), podemos ler que, além do intuito de combater os preconceitos dos teólogos e de se defender da acusação de ateísmo, Espinosa aponta a defesa da "[...] liberdade de filosofar e de exprimir nossa opinião" como uma das razóes que o levaram a redigir o Tratado Teológico-Político. (TTP, 2003, p. XV) Assim, ele procura não apenas defender a liberdade de filosofar, mas busca ainda demonstrar que impedir essa liberdade é impedir a segurança e a paz da república. Desse modo, o Cap. XX ("Onde se demonstra que num Estado livre é lícito a cada um pensar o que quiser e dizer aquilo que pensa”) do Tratado Teológico-Político conclui, de certa forma, o que foi apontado em seu prefácio, pois, se, no prefácio, Espinosa apresentava os impedimentos para a paz e para a liberdade política, no último capítulo do tratado, o autor irá demonstrar a necessidade dessa liberdade para a paz. Espinosa salienta ser impossível que a vontade de um homem possa estar completamente sujeita à jurisdição alheia, uma vez que ninguém pode transferir (nem ser coagido a tanto) o seu direito natural ou a sua faculdade de raciocinar livremente e ajuizar sobre qualquer coisa. ${ }^{15}$ Por conseguinte, assevera Espinosa,

\footnotetext{
${ }^{15}$ A abertura do texto é uma crítica à violência. A violência na sua forma suprema não é o domínio sobre os corpos, mas o domínio exercido sobre os espíritos. Se levarmos em conta o direito natural, não pode haver um governo plenamente violento, pois os homens não renunciam ao seu direito natural de pensar. Mas isso acontece todas as vezes que os homens são induzidos a isso sem perceber: "Bem sei que o discernimento pode ser influenciado de muitas maneiras, algumas quase inacreditáveis, a ponto de, mesmo náo estando diretamente dominado por outrem, ele depender de tal maneira de sua palavra
} 
[...] todo poder exercido sobre o foro íntimo se tem por violento, da mesma forma que se considera ultrajar e usurpar o direito dos seus súditos um soberano que queira prescrever a cada um o que deve admitir como verdadeiro e como falso [...]; porque tudo isso pertence ao direito individual e ninguém, mesmo que quisesse, poderia renunciar-lhe. (TTP, 2003, p. 300, grifo nosso).

Diferentemente de Espinosa, para Hobbes, os homens renunciam ao direito natural por meio de um contrato social pelo qual transferem todo o poder ao soberano. Ninguém contrata com o soberano. Ele está acima dos cidadãos e é transcendente ao social. Os homens contratam entre si e instituem o soberano acima deles. Por isso, o direito do soberano de "[...] ser juiz de quais as opiniốes e doutrinas que são contrárias à paz, e quais as que lhe são propícias." A ele cabe também julgar “[...] em que ocasiōes, até que ponto e o que se deve conceder àqueles que falam a multidóes de pessoas, e quem deve examinar as doutrinas de todos os livros antes de serem publicados." Para Hobbes, visto que as açôes dos homens derivam de suas opiniôes, e é no bom governo das opiniốes que consiste o bom governo das açóes dos homens, “[...] tendo em vista a paz e a concórdia entre eles [...] compete ao detentor do poder soberano ser o juiz, ou constituir todos os juízes de opinióes e doutrinas, como uma coisa necessária para a paz, evitando assim a discórdia e a guerra civil."(HOBBES, 1983, p. 109-110).

\section{Por outro lado, no Tratado Teológico-Político,}

Espinosa náo aceita a idéia do pacto como transferência total do direito natural ou da potência individual a um outro: o pacto é descrito como um acordo mútuo em que cada indivíduo concorda em que o direito natural de cada um a todas as coisas seja exercido coletivamente e náo mais seja determinado pelo apetite de cada um e sim pela potência da vontade de todos em conjunto. (CHAUÍ, 2003, p. 165).

Assim, segundo Espinosa, a democracia é o mais natural dos regimes políticos, uma vez que realiza o desejo natural de governar e não ser governado e conserva a igualdade que os homens tinham em estado natural. Assim, a única coisa a que o indivíduo renunciou foi ao seu direito de agir de acordo apenas com o que lhe dita a sua mente, ou seja, ao direito de agir segundo a

que seja possível e mesmo correto considerá-lo subjugado." (TTP, 2003, p. 300). A forma mais perfeita de violência é a violência invisível, quando os homens não a percebem. E a religião pode fazer isso. 
sua própria lei. Por isso, declara Espinosa, ninguém pode atuar ${ }^{16}$ contra as determinaçóes dos poderes soberanos, sem lesar o direito destes,

[...] mas pode pensar, julgar e, por conseguinte, dizer absolutamente tudo, desde que se limite só a dizer ou a ensinar e defenda o seu parecer unicamente pela razão, sem fraudes, cólera, ódio ou intenção de introduzir por sua exclusiva iniciativa qualquer alteração no Estado. (TTP, 2003, p. 303, grifo nosso).

Dessa maneira, Espinosa defende que o Estado deve conceder a liberdade de opinião aos seus cidadãos. Além disso, deve governar os homens

[...] de modo que, professando embora publicamente opiniôes diversas e até contrárias, vivam apesar disso em concórdia. E não há dúvida de que essa maneira de governar é a melhor e a que traz menos inconvenientes, porquanto é a que mais se ajusta à natureza humana. Com efeito, num Estado democrático (que é o que mais se aproxima do estado de natureza), todos [...] se comprometeram pelo pacto a sujeitar ao que for comumente decidido os seus atos, mas não os seus juizos e raciocínios. [...] Sendo assim, quanto menos liberdade de opiniâo se concede aos homens, mais nos afastamos do estado mais parecido com o de natureza e, por conseguinte, mais violento é o poder. (TTP, 2003, p. 307-308, grifo nosso).

Espinosa afirma que o Estado poderá punir e tem o direito (já que o direito é inseparável do poder, para o seu exercício ${ }^{17}$ de punir aqueles que não estiverem absolutamente de acordo consigo, em todas as matérias. Porém, ele argumenta que isso não é vantajoso para o Estado. "Não contesto", enfatiza Espinosa, "[...] que tenham direito a governar por meio da violência e a condenar cidadáos à morte pelos motivos mais fúteis. Ninguém, todavia, pretenderá que isso seja compatível com o que dita a razão.” O que a razão

\footnotetext{
${ }^{16}$ Cabe lembrar aqui a diferença entre opinião política e ato público: o soberano tem o poder de dizer quais opiniốes não serão aceitas no Estado e quais sâo criminosas. Por exemplo, no que diz respeito a opiniôes racistas, o Estado não pode impedir que o indivíduo as tenha e que pense dessa forma. Mas, se o racismo for proibido como crime pelas leis civis de um Estado, o soberano tem o direito ou o poder de punir as açóes consideradas racistas.

17 "Para Espinosa, todo direito é um poder, isto é, nosso direito vai até onde possuirmos poder para realizálo e força para garanti-lo. Por este motivo, diferentemente de Hobbes, Espinosa afirma que o direito civil [...] e o Estado civil [...] não nascem contra o direito natural e o estado de natureza, mas para realizá-los concretamente. [...] Eis por que Espinosa define o poder soberano exatamente como definira o direito natural: é soberano aquele que tem o poder para fazer valer seus direitos, e terá tanto direito quanto poder tiver para impor, defender e garantir esse direito-poder." (CHAUÍ, 1995, p. 75-76).
} 
diz para a soberania? Não é vantajoso fazer isso, pois isso coloca o Estado em risco. Assim, "[...] dado que é impossível tal procedimento sem pôr em grave risco todo o Estado, podemos até negar que eles tenham esse poder e, por conseguinte, o direito absoluto de atuar desse modo."(TTP, 2003, p. 301, grifo nosso). ${ }^{18}$ Portanto, assinala Espinosa:

Se ninguém pode renunciar à sua liberdade de julgar e pensar o que quiser, e se cada um é senhor dos seus próprios julgamentos por superior direito da natureza, jamais será possível, numa comunidade política, tentar sem resultados funestos que os homens, apesar de terem opinióes diferentes e até opostas, não digam nada que não esteja de acordo com aquilo que prescrevem as autoridades. [...] um poder que negue aos indivíduos a liberdade de dizer e de ensinar o que pensam será, por conseguinte, um poder violento; pelo contrário, um poder que lhes conceda essa liberdade será um poder moderado. (TTP, 2003, p. 302).

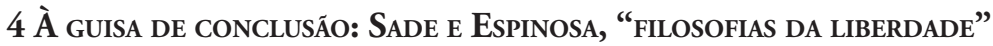

A segunda seção do texto Franceses, mais um esforço se quereis ser Republicanos, intitulada "Os Costumes", tem início com estas palavras:

Após ter demonstrado que o teísmo de modo algum convém a um governo republicano, parece-me necessário provar que os costumes franceses também lhe são inconvenientes. Este artigo é tanto mais essencial quanto são os costumes que servirão de motivo à lei que se vai promulgar. Franceses, sois esclarecidos demais para não perceber que um novo governo precisa de novos costumes. É impossível que o cidadáo de um Estado livre se conduza como o escravo de um rei déspota. (SADE, 1999, p. 136-137).

A partir de tais consideraçóes, o autor defende a necessidade de se garantir a liberdade de consciência e a liberdade de imprensa, uma vez que concedê-las "[...] é quase o mesmo que conceder a liberdade de agir, e que, com exceção do que choca diretamente as bases do governo, restará muito menos crimes a punir, pois [...] há bem poucas açóes criminosas numa sociedade que tem por base a liberdade e a igualdade". (SADE, 1999, p. 137, grifo nosso). Agora, resta saber se tais pontos de vista podem ser conciliados com os de Espinosa.

Como já vimos na análise do prefácio do Tratado Teológico-Político, a esperança se transforma em segurança, quando não temos mais dúvida de

\footnotetext{
${ }^{18}$ Cabe lembrar ainda que, para Espinosa, quanto mais um Estado usa o poder repressivo, mais fraco (politicamente) ele é.
} 
que um bem virá. ${ }^{19}$ Em outras palavras, a segurança é a esperança, quando se tornou estabilizada, permanente. No Tratado Político, Espinosa afirma que o fim em vista do qual se funda o Estado não é senão a paz e a segurança da vida (ESPINOSA,1983, TP5/2) ${ }^{20}$ e, no Tratado Teológico-Politico, ele ressalta que o verdadeiro fim do Estado é a liberdade (TTP, 2003, p. 302). Ora, em que sentido devemos compreender essas afirmaçóes? Espinosa assevera que o fim último do Estado "[...] não é dominar nem subjugar os homens pelo medo e submetê-los a um direito alheio." Pelo contrário: a finalidade do Estado é libertar o individuo do medo, "[...] a fim de que ele viva, tanto quanto possível, em segurança, isto é, a fim de que mantenha da melhor maneira, sem prejuízo para si ou para os outros, o seu direito natural a existir e a agir." O fim do Estado é fazer com que os homens "[...] possam usar livremente a razão e que não se digladiem por ódio, cólera ou insídia."(TTP, 2003, p. 302) Em outras palavras, a finalidade do Estado é a segurança. Ora, a política, por meio das leis, tira-nos a dúvida do futuro e nos dá segurança. E, nessa medida, ela nos dá a paz. Não pode haver paz, se não houver liberdade, donde se conclui que a liberdade não é perigosa para a paz. Pelo contrário, ela é a condição da paz: isso é revolucionário, no pensamento de Espinosa. ${ }^{21} \mathrm{E}$ Sade certamente tinha plena consciência disso.

VIDEIRA, Mario. Politics in the boudoir; Spinozan echoes in Sade. Trans/Form/Ação, Marília, v. 39, p. 9-22, 2016. Ediçăo Especial.

\begin{abstract}
This article aims to investigate the interpretation by the Marquis de Sade of Spinoza's Theological-Political Treatise. Sade's interpretation appears in a very peculiar work which defies all rigid attempts of classification: La Philosophie dans le Boudoir. In the "Fifth Dialogue", Sade inserts a pamphlet entitled "Yet another effort, Frenchmen, if you would become Republicans". Through the employment of a metalinguistic device - a book inside a book - politics is now introduced into the boudoir, and the reader becomes aware that Eugénie's education is not merely sexual, but also philosophical and political. Through his critique of Christianity in the first section of the pamphlet,
\end{abstract}

\footnotetext{
${ }^{19}$ Lembremos que, por segurança, Espinosa entende "[...] a alegria nascida de uma coisa futura ou passada, acerca da qual já não há causa de dúvida."

${ }^{20}$ Espinosa. Tratado Político, 1983 (doravante: TP). TP5/2.

${ }^{21}$ Espinosa escreve que "[...] a liberdade de opiniáo não só pode ser concedida sem que a paz do Estado, a piedade e o direito dos poderes soberanos fiquem ameaçados, como inclusive o deve ser, se se quiser preservar tudo isso." E conclui: "Não há nada melhor para a segurança do Estado que fazer consistir a piedade e a religiấo unicamente na prática da caridade e da justiça e limitar o direito das autoridades soberanas, tanto em matéria sagrada como profana, aos atos, deixando a cada um a liberdade de pensar aquilo que quiser e de dizer aquilo que pensa." (TTP, 2003 p. 309-310, grifo nosso).
} 
Sade argues that tyranny and religious superstition are closely related and that theology is one of the main foundations of political power.

KEYWORDS: Marquis de Sade. Baruch Spinoza. Tyranny and religious superstition. Philosophy in the Bedroom. Theological-Political Treatise.

\section{REFERÊNCIAS}

CHAUI, M. Espinosa: uma filosofia da liberdade. São Paulo: Moderna, 1995. . Introdução à história da filosofia. São Paulo: Companhia das Letras, 2002. V. 1 . Política em Espinosa. São Paulo: Companhia das Letras, 2003.

. O retorno do teológico-político”. In: CARDOSO, S. (Org.). O retorno ao republicanismo. Belo Horizonte: Editora da UFMG, 2004. p. 93-133.

ESPINOSA, B. Ética (Parte III). Tradução de J. Ferreira Gomes. São Paulo: Abril Cultural, 1983. (Os Pensadores).

. Tratado político. Tradução de M. de Castro. São Paulo: Abril Cultural, 1983. (Os Pensadores).

- Tratado teológico-político. Tradução, introdução e notas de D. Pires Aurélio. São Paulo: Martins Fontes, 2003.

HOBBES, T. Leviatã ou matéria, forma e poder de um Estado eclesiástico e civil. Tradução de J. P. Monteiro e M. B. N. Silva. São Paulo: Abril Cultural, 1983. (Os Pensadores).

KLOSSOWSKI, P. Sade meu próximo. Tradução de Armando Ribeiro. São Paulo: Brasiliense, 1985.

LEFORT, C. Sade: o boudoir e a cidade. In: Desafios da escrita política. Tradução de Eliana de Melo Souza. São Paulo: Discurso, 1999.

MOTHU, A. Les lectures "nécessaires" du Marquis de Sade [20--?]. Disponível em: <http://aura.u-pec.fr/scd/lc3-5d.htm>. Acesso em: 10 jun. 2016.

SADE, M. de, A Filosofia na alcova. Tradução de Augusto Contador Borges. São Paulo: Iluminuras, 1999. Justine, philosophy in the Bedroom, and other writings. Translation by Richard Seaver and Austryn Wainhouse. New York: Grove Press, 1990.

Recebido / Received: 06/06/2016 